\title{
Behavioral flexibility of a group of bearded capuchin monkeys (Cebus libidinosus) in the National Park of Brasília (Brazil): consequences of cohabitation with visitors
}

\author{
Sabbatini, G. ${ }^{\mathrm{a}, \mathrm{b}}$, Stammati, M. ${ }^{\mathrm{a}, \mathrm{b}}$, Tavares, $M C H .^{\mathrm{c}}$, and Visalberghi, E. ${ }^{\mathrm{b} *}$ \\ aDipartimento di Biologia Animale e dell’Uomo, Università di Roma "La Sapienza", \\ Viale dell'Università 32, 00185, Rome, Italy \\ bUnità di Primatologia Cognitiva, Istituto di Scienze e Tecnologie della Cognizione, \\ Consiglio Nazionale delle Ricerche, Via Ulisse Aldrovandi 16/B, 00197, Rome, Italy \\ 'Laboratório de Neurociências e Comportamento, Departamento de Ciências Fisiológicas - CFS, \\ Instituto de Biologia - IB, Universidade de Brasilia - UnB, \\ CEP 70910-900, Brasilia, DF, Brazil \\ *e-mail: elisabetta.visalberghi@istc.cnr.it
}

Received August 1, 2006 - Accepted February 16, 2007 - Distributed November 30, 2008

(With 4 figures)

\begin{abstract}
Increasing urbanization and deforestation have enhanced the opportunities of contact between humans and monkeys and the impact of human activities on primate behavior is receiving growing attention. This study explores whether activity budgets and diet of a group of capuchin monkeys (Cebus libidinosus) inhabiting the area of the swimming pools of the National Park of Brasília is affected by the presence of visitors providing food to them. During one year, both in the dry and the wet seasons, we scored capuchins' behavior via scan sampling every ten minutes. Results showed that this group spent less time foraging for wild foods than other comparable groups living in similar habitats. Moreover, capuchins relied more on human food during the dry season, when pulpy fruits were less available, than in the wet season. Our findings confirm other studies on different monkey species that have shown that access to human food decreases the time spent foraging for wild food and the home range size. They also show that capuchins are able to modify their diet, to exploit alternative food sources, and to change their activity budget in response to the availability of new food opportunities and to seasonal food availability.
\end{abstract}

Keywords: Cebus libidinosus, activity budgets, diet, human food, seasonality.

Flexibilidade comportamental de um grupo de macacos-prego (Cebus libidinosus) no
Parque Nacional de Brasília (Brasil): consequiências da convivência com os visitantes

Resumo

Recentemente, o impacto de atividades humanas sobre o comportamento de primatas tem recebido maior importância dado o crescente desmatamento e urbanização, que têm favorecido o aumento do contato entre humanos e macacos. O presente estudo descreve os padrões de atividade e a dieta de um grupo de macacos-prego (Cebus libidinosus) que vive no Parque Nacional de Brasília. O Parque é freqüentado diariamente por visitantes, de modo que os animais estão habituados à presença humana, bem como ao consumo de itens de sua dieta. Observações comportamentais do grupo foram realizadas ao longo de um ano, compreendendo a estação seca e a chuvosa, utilizando-se registro de varredura a cada 10 minutos. Resultados obtidos indicaram que o grupo despendeu menos tempo forrageando itens naturais do que outros grupos vivendo em habitats similares. Além disso, durante a estação seca, quando há menor disponibilidade dos frutos de polpa, os macacos-prego alimentaram-se mais de itens da dieta humana como uma fonte alternativa de recurso. Como demonstrado em estudos anteriores realizados com outras espécies de macacos, a alimentação baseada em itens da dieta humana pareceu diminuir a motivação dos animais para forragear no seu habitat natural, assim como promoveu a redução do tempo gasto no forrageamento e a redução de sua área de uso. Nossos resultados indicaram ainda que o consumo de comida humana reflete o caráter adaptável dos animais em explorar fontes alternativas de recurso, bem como a sua habilidade em modificar a sua dieta e padrões de comportamento face às mudanças ambientais.

Palavras-chave: Cebus libidinosus, padrões de atividade, dieta, comida humana, sazonalidade. 


\section{Introduction}

The neotropical primate species Cebus libidinosus, formerly considered a subspecies of Cebus apella, belongs to the Cebidae family, Platirrhinae infraorder (Groves, 2001). Cebus libidinosus is distributed in Bolivia, northwestern Argentina, central and northeast Brazil, the Pantanal of Mato Grosso, and eastern Paraguay (Fragaszy et al., 2004). Capuchin monkeys live in a great variety of habitats. They are present in almost all tropical forest habitats, both rain forest and deciduous forest (Janson, 1985); capuchins can also live in limited or secondary forest fragments, and do not excessively resent human presence (Hawkes et al., 1982). Capuchins are omnivorous; their diet is constituted principally of fruits, but they also eat flowers, buds, roots, arthropods, small amphibians and reptiles, eggs, nestling birds and small mammals (Fragaszy et al., 2004). Capuchins' feeding techniques, that include complex and unusual manipulative skills, allow them to exploit food sources that are not easily accessible to other primate species.

Behavioral flexibility is adaptive for coping with environmental change (Lee, 1991) and primates' tolerance to environmental change lies in the ability to locate, consume, and process adequate food (Chivers, 1991). During periods of low resource availability, most species of capuchins living in seasonal habitats modify their diet, switching to alternative resources, and/or adopt behavioral strategies to enhance food acquisition and reduce energy expenditure (e.g., Brown and Zunino, 1990; Peres, 1994; Terborgh, 1983), and/or modify group dimension and individual distribution when foraging. When food patches are depleted or food is scarce, capuchins form sub-groups, which enable a better use of a large number of dispersed small food patches, and minimize travel cost and feeding competition (e.g., Phillips, 1995; Izar, 2004), or exploit alternative food types (e.g., Chapman and Fedigan, 1990; Robinson, 1986).

Human food, such as cultivated plants and garbage, can become part of monkeys' diet (Lee et al., 1986; Richard et al., 1989) and affect their activity patterns (Fa, 1986; Forthman Quick, 1986; Saj et al., 1999). Whereas the vast majority of the studies on the impact of human activities concern Old World monkeys, recently the capuchin monkeys' behavior has received growing attention in this respect (Galetti and Pedroni, 1994; Mikich, 2005; Siemers, 2000). In fact, the development, urbanization and deforestation of South American countries has enhanced the opportunities of contact between humans and monkeys and aggressive interactions are becoming common, especially with capuchins (Fragaszy et al., 2004; Mendes et al., 2005).

In this sense, we investigated the activity budgets and diet of a group of wild capuchin monkeys living in a semi-deciduous forest in the National Park of Brasília. In this habitat, the amount of food, especially fruit, changes throughout the year, being less abundant in the dry season than in the wet season. The capuchins' home range included the area of the swimming pools of the Park and the monkeys were used to visitors' presence and to eat the food brought by visitors into the Park.

The first aim of this study was to assess whether seasonal differences in the availability of wild food, 1 and whether the presence and abundance of human food (We refer to the food the monkeys find in the forest as wild food, and to the food brought by visitors to the Park, or bought by them into the Park, as human food), affected the monkeys' activity budgets and diet. To do so, we compared the diet and activity budgets in the dry and the wet season and on the days in which human food was scarce (when there were few visitors) and days on which human food was abundant (since there were many visitors).

The second aim was to examine whether relying on human food altered their activity budgets, diet and substrate use of our subjects. To do so we compared our findings with those reported in the literature for capuchin monkeys living in similar habitats and facing comparable seasonal differences in food abundance, but that cannot rely on human food as an alternative resource.

\section{Material and Methods}

\subsection{Study area}

The study was conducted in the Parque Nacional de Brasília, Brazil $\left(15^{\circ} 35^{\prime}-15^{\circ} 45^{\prime} \mathrm{S}\right.$ and $\left.48^{\circ} 05^{\prime}-47^{\circ} 53^{\prime} \mathrm{W}\right)$. The Park has an area of 30,000 hectares, constituted of typical scrub savanna (cerrado) and gallery forests, and is characterized by a tropical climate with two distinct seasons (Koppen's Aw), the wet season (October to April) and the dry season (May to September). During the study period mean temperature was $21.9{ }^{\circ} \mathrm{C}$ (varying from 11.7 and $30.3{ }^{\circ} \mathrm{C}$ ) and annual precipitation was $1587.6 \mathrm{~mm}(1524.3 \mathrm{~mm}$ in the wet season and $63.3 \mathrm{~mm}$ in the dry season; data from the Climatologic Station of the IBGE-RECOR Ecological Reserve, Brasília). The Park is visited by almost 260,000 people per year (online IBAMA database). In particular, our study took place in an area where two natural swimming pools are surrounded by semi-deciduous forest and paths; this area is frequented by large groups of visitors for sports and leisure.

\subsection{Subjects and data collection}

Observations were made on a group of capuchin monkeys that frequented the area of the two swimming pools (especially one) all year round. The group was habituated to visitors' presence and to eating human food by obtaining it directly from visitors, taking their leftovers, or stealing it (Sabbatini et al., 2006). During the study period, group size varied between 6 and 8 animals due to two births. Based on estimated age, subjects were assigned to the following age classes: infants (0-1 years), young ( $1-5$ years) and adults ( $>5$ years). The group consisted of one adult male, two adult females, two young males, one young female and two infants. 
The data were collected between August 2003 and July 2004. Preliminary observations were made to habituate the group to human observers and to ensure interobserver reliability in identifying individuals and scoring behaviors. Behavioral data were collected via 10 minutes scan sampling (Altmann, 1974) and samples were taken in two different daytime blocks: one block was from 6:30 AM to 1:00 PM, the other from 1:00 PM to dusk (6:00-6:30 PM). Sampling efforts in the two time blocks were uniformly distributed. Out of the 100 days in which we tried to track the group, 72 days resulted in group following, for a total of 254 hours and 6,594 scan samples. Observers collected data on each individual's location (in the forest or the swimming pool), food types eaten, substrate height (height classes: $0 \mathrm{~m}$; 0-5 m; 5-10 m; 10-15 m; 15-20 m; >20 m) and behavior. The behavioral categories scored were: Rest - animal stopped, lying or sitting down; Move: any spatial movement of the animal; Feeding - the individual chews or swallows food; Foraging - the individual holds, visually explores, sniffs, manipulates (digs, breaks, pounds, rips, rubs, peels), or bites a potential food source; Social behavior - the individual grooms, plays, performs affiliative/aggressive behaviors; Human-capuchin interaction - the individual approaches, contacts, or threatens a human being and vice versa.

Once a week, for one day, the swimming pool was emptied for cleaning and the number of visitors and the human food potentially available to the monkeys decreased dramatically. Observations were made both when the swimming pool was full of water $(72.65 \%$ of scans) and when the pool was empty $(23.35 \%$ of scans). The number of visitors present in the area was estimated 2-3 times per day by two observers standing by the swimming pool that counted independently the number of visitors present in the swimming pool area. The two counts, that never differed more than 1-2 units, were successively averaged. The daily number of visitors was calculated by averaging the 2-3 counts performed during the day. The number of visitors was closely related to the amount of human food available for the monkeys (Sabbatini and Stammati, pers. obs.), for the more visitors were at the swimming pool the more food was present in the garbage bins, or given to the monkeys, or could potentially be stolen. Therefore, we will refer to the days in which there were few visitors as "scarce human food days" and to those in which they were many as "abundant human food days".

\subsection{Data analysis}

Proportions of scans devoted to the different activities were calculated for each subject. Infants' behavior was considered only from February 2004, when the newborns were about six months old and began to behave independently from their mothers.

To determine activity budgets we calculated the sum of the different activities for each individual by season (dry/wet) and according to whether the human food was abundant or scarce and then divided it by the total number of scans recorded for each individual in the period considered. To assess differences between activity budgets and substrate height used in the wet and dry seasons, and when human food was scarce or abundant, we used the Wilcoxon matched pairs test. To assess whether time spent by capuchins in the forest and in the swimming pool area differed when human food was scarce or abundant we performed the $\chi^{2}$ test. Sex and age differences were analyzed by means of the Mann-Whitney U test. To assess similarity between capuchins' diet (in terms of wild and human food) during dry and wet seasons, and when human food was scarce or abundant, we used Schoener's index (1970) of diet overlap, that evaluates the percentage of diet similarity between periods or months.

\section{Results}

\subsection{Visitor presence}

During the dry season the mean number of visitors per day was $178.28( \pm 20.95)$ and during the wet season $95.93( \pm 23.02)$; these values were not statistically different $\left(\mathrm{N}_{1}=17 ; \mathrm{N}_{2}=81 ; \mathrm{t}_{96}=0.78 ; \mathrm{ns}\right)$. When the swimming pool was empty the mean number of visitors per day was $15.47( \pm 0.49)$, while when the swimming pool was full, the mean number of visitors per day was 128.80 ( \pm 26.05$)$; these values were statistically different $\left(\mathrm{N}_{1}=9 ; \mathrm{N}_{2}=89 ; \mathrm{t}_{96}=-2.37 ; \mathrm{p}<0.01\right)$.

\subsection{Activity budgets, forest strata use and seasonality}

Overall, as shown in Figure 1, for most of the time, capuchins moved $(41 \%)$ and rested $(15 \%)$. Foraging and feeding on wild and human food (pooled) accounted for a total of $34 \%$ of scans, the majority of which concerned wild food. Capuchins interacted with humans for $2 \%$ of scans and this value remained constant between seasons. Age differences were evident for resting behavior: throughout the study period, adults rested significantly

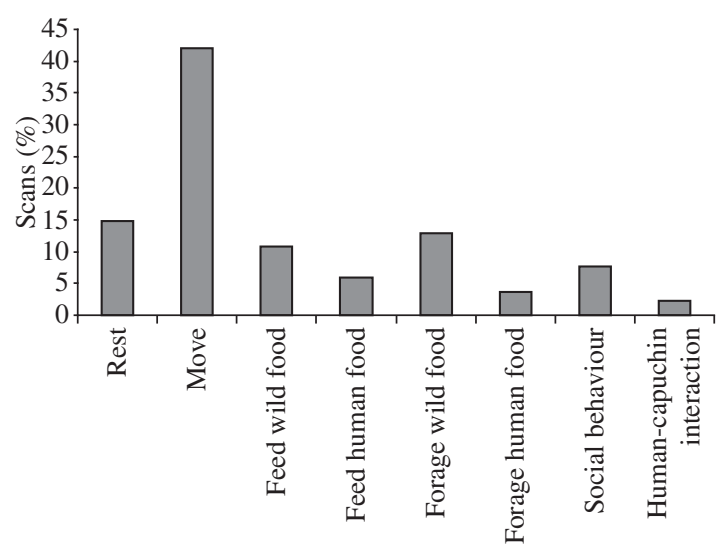

Figure 1. Capuchins' activity budgets throughout the study period, as percent of 10 minutes scans. 
more than juveniles (Mann-Whitney test, $\mathrm{U}=0 ; \mathrm{N}_{1}=3$; $\left.\mathrm{N}_{2}=5 ; \mathrm{p}<0.05\right)$.

During the wet season capuchins ate more wild food (Wilcoxon test, $\mathrm{Z}=2.10 ; \mathrm{T}=3 ; \mathrm{N}=8 ; \mathrm{p}<0.05$; see Figure 2), while the opposite is true for human food, that was eaten significantly more during the dry season (Wilcoxon test, $\mathrm{Z}=2.38 ; \mathrm{T}=1 ; \mathrm{N}=8 ; \mathrm{p}<0.01$ ). During the wet season juveniles foraged significantly more than adults (Mann-Whitney test, $\mathrm{U}=0 ; \mathrm{N}_{1}=3 ; \mathrm{N}_{2}=5$; $\mathrm{p}<0.05)$ whereas during the dry season they socially interacted more than adults (Mann-Whitney test, $\mathrm{U}=0$; $\left.\mathrm{N}_{1}=3 ; \mathrm{N}_{2}=5 ; \mathrm{p}<0.05\right)$.

Overall, as shown in Figure 3, capuchins spent most of their time between ground level and $5 \mathrm{~m}(51.86 \%)$ and during the dry season they used the substrates comprised between 15 and $20 \mathrm{~m}$ significantly more than during the wet season (Wilcoxon test, $\mathrm{Z}=1.99 ; \mathrm{T}=1 ; \mathrm{N}=8 ; \mathrm{p}<0.05$ ). Sex and age did not influence substrate height use.

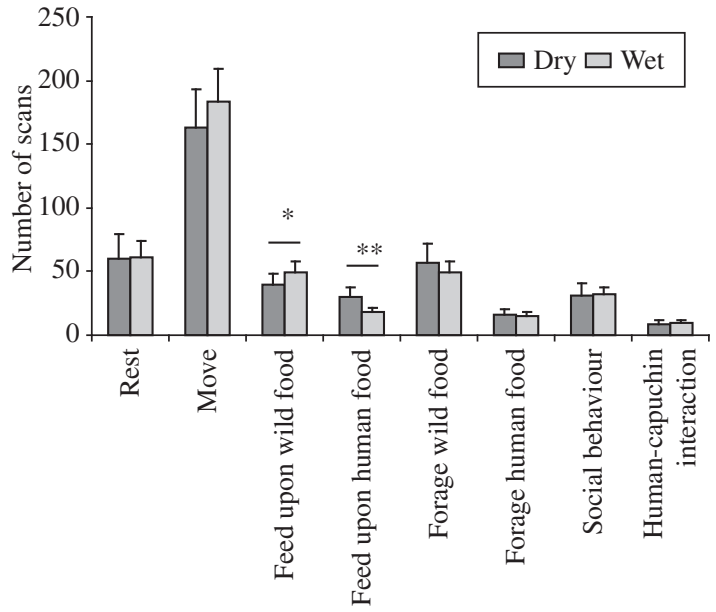

Figure 2. Capuchins' activity budgets during dry season (grey bars) and wet season (black bars), expressed as mean number of scans ( \pm standard error) in which each behavior was recorded. $* \mathrm{p}<0.05 ; * * \mathrm{p}<0.01$.

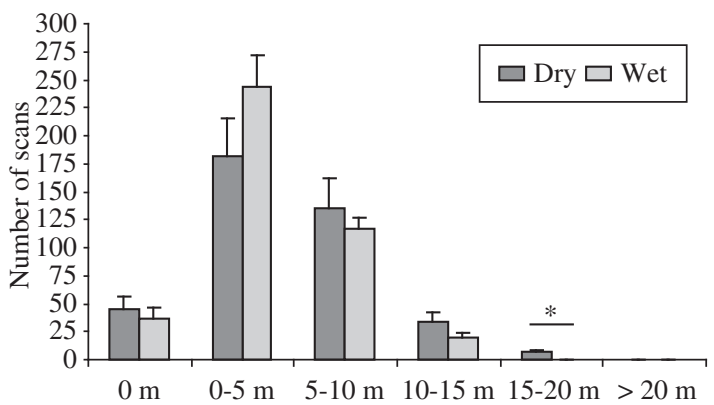

Figure 3. Capuchins' use of the forest strata during the dry season (grey bars) and the wet season (black bars), expressed as average number of scans ( \pm standard error). $* \mathrm{p}<0.05$.

\subsection{Diet and seasonality}

We observed capuchins eating 47 identified plant species, belonging to 29 different families (Table 1) and a variety of human foods, ranging from fruits to sweets and junk food (Table 2). They devoted more time eating wild than human food $(64.85 \%$ and $35.15 \%$ respectively; 1101 scans). Throughout the year capuchins ate invertebrates (grasshoppers, ants, spiders, butterflies, balm crickets, larvae inside branches, etc.) and small vertebrates such as lizards, geckos, frogs, nestlings and bats. Sex and age did not affect time spent eating wild and human food.

Season affected the type of food eaten. Capuchins ate more human food and seeds during the dry season (Wilcoxon test, $\mathrm{Z}=2.38 ; \mathrm{T}=1 ; \mathrm{N}=8 ; \mathrm{p}<0.05$ and $\mathrm{Z}=2.20 ; \mathrm{T}=0 ; \mathrm{N}=8 ; \mathrm{p}<0.05$, respectively) and ate more fruit and invertebrates during the wet season (Wilcoxon test, $\mathrm{Z}=2.38 ; \mathrm{T}=1 ; \mathrm{N}=8 ; \mathrm{p}<0.05$ and $\mathrm{Z}=2.20 ; \mathrm{T}=0$; $\mathrm{N}=8 ; \mathrm{p}<0.05$, respectively). The most consumed wild foods during the dry season were flowers and fruits of Inga ingoides, the seeds of Luehea divaricata, the fruits of Copaifera langsdorfii, and of Ficus spp., and during the wet season the inflorescences and infructescences of Piper spp., the fruits of Zanthoxylum rhoifolium, of Psidium guajava, and of Ocotea sp., and invertebrates. Schoener's diet overlap index between dry and wet season was $46.89 \%$.

\subsection{Human food and capuchins' behavior}

When human food was scarce capuchins spent more time in the forest than when human food was abundant $\left(\chi^{2}\right.$ with Yates' correction $\left.=16.04 ; \mathrm{df}=1 ; \mathrm{p}<0.001\right)$. In particular, the standardized residuals showed that when human food was scarce capuchins spent less time by the swimming pool (standardized residuals $=-2.20$ ) and more time in the forest than expected (standardized residuals $=2.69$ ). Therefore it is not surprising that capuchins ate significantly more wild food when human food was scarce (Wilcoxon test, $\mathrm{Z}=2.38 ; \mathrm{T}=1 ; \mathrm{N}=8$; $\mathrm{p}<0.05$; see Figure 4).

When human food was abundant, adults rested more than juveniles (Mann-Whitney test, $\mathrm{U}=0 ; \mathrm{N}_{1}=3$; $\left.\mathrm{N}_{2}=5 ; \mathrm{p}<0.05\right)$ and were less involved in social interactions than juveniles (Mann-Whitney test, $\mathrm{U}=0 ; \mathrm{N}_{1}=3$; $\mathrm{N}_{2}=5 ; \mathrm{p}<0.05$ ). When human food was scarce, juveniles foraged more on wild foods than adults (Mann-Whitney test, $\left.\mathrm{U}=0 ; \mathrm{N}_{1}=3 ; \mathrm{N}_{2}=5 ; \mathrm{p}<0.05\right)$. Schoener's diet overlap index between the days in which human food was scarce and abundant was $69.59 \%$.

\section{Discussion}

Seasonality of behavior and diet is common in wild capuchins (Fragaszy et al., 2004). Our study extended these findings by investigating how capuchins succeed in exploiting food sources only recently introduced into their habitat, and that are not among those typically eaten by the species. The ability to incorporate human food 
Table 1. Natural foods eaten/foraged by the study group (data from scan and ad libitum sampling).

\begin{tabular}{|c|c|c|c|c|c|}
\hline Species & $\begin{array}{c}\text { Part } \\
\text { eaten* }\end{array}$ & Month** & $\begin{array}{c}\text { Density }^{* * * *} \\
\left(\text { ind.ha }^{-1}\right)\end{array}$ & $\begin{array}{c}\text { Percentage of } \\
\text { feeding records }\end{array}$ & $\begin{array}{c}\text { Percentage } \\
\text { of foraging } \\
\text { records }\end{array}$ \\
\hline \multicolumn{6}{|l|}{ ANACARDIACEAE } \\
\hline Mangifera indica & $\mathrm{Fr}$ & Nov., Jan.-Feb. ${ }^{\mathrm{w}}$ & _ & 0.36 & 0.56 \\
\hline Tapirira guianensis & $\mathrm{Fr}$ & Sep.-Nov., Jan. ${ }^{\text {B }}$ & 196.80 & 1.82 & - \\
\hline \multicolumn{6}{|l|}{ ANNONACEAE } \\
\hline Xylopia sp. & $\mathrm{Fr}$ & Aug. ${ }^{\mathrm{D}}$ & - & - & - \\
\hline unid. species & $\mathrm{Se}$ & Jan.-Feb. ${ }^{\mathrm{W}}$ & - & - & - \\
\hline \multicolumn{6}{|l|}{ BROMELIACEAE } \\
\hline Bromelia laciniosa & $\mathrm{Sp}, \mathrm{Le}$ & Aug.-Sept., Apr. ${ }^{\text {В }}$ & - & 1.0 & 0.65 \\
\hline Tillandsia $\mathrm{sp}$. & Le & July, Mar. $^{\mathrm{B}}$ & - & - & - \\
\hline \multicolumn{6}{|l|}{ BURSERACEAE } \\
\hline Protium sp. & $\mathrm{Fr}$ & Aug. ${ }^{\text {D }}$ & - & - & - \\
\hline \multicolumn{6}{|l|}{ CAESALPINACEAE } \\
\hline Bauhinia rufa & $\mathrm{Se}$ & Sept. ${ }^{D}$ & 424.20 & - & - \\
\hline Copaifera langsdorffii & $\mathrm{Fr}$ & July-Aug. ${ }^{\mathrm{D}}$ & 65.30 & 3.54 & - \\
\hline \multicolumn{6}{|l|}{ CECROPIACEAE } \\
\hline unid. species & Le & - & - & - & - \\
\hline \multicolumn{6}{|l|}{ CLUSIACEAE } \\
\hline Calophyllum brasiliense & $\mathrm{Fr}$ & Jan. $^{\mathrm{w}}$ & 36.90 & - & - \\
\hline \multicolumn{6}{|l|}{ CYPERACEAE } \\
\hline Cyperus haspan & $\mathrm{Fr}$ & Jan. $^{\mathrm{W}}$ & - & - & - \\
\hline \multicolumn{6}{|l|}{ HIPPOCRATACEAE } \\
\hline Cheiloclinium cognatum & $\mathrm{Fr}$ & Aug. ${ }^{D}$ & - & - & - \\
\hline \multicolumn{6}{|l|}{ LAURACEAE } \\
\hline Ocotea sp. & - & Nov. ${ }^{\mathrm{W}}$ & - & 1.82 & 0.09 \\
\hline Persea americana & $\mathrm{Fr}$ & Feb. ${ }^{\mathrm{W}}$ & - & - & - \\
\hline \multicolumn{6}{|l|}{ LECYTHIDACEAE } \\
\hline Cariniana estrellensis & $\mathrm{Se}$ & July-Sept. ${ }^{\mathrm{D}}$ & 147.70 & 0.36 & 8.53 \\
\hline \multicolumn{6}{|l|}{ LEGUMINOSAE } \\
\hline Andira sp. & $\mathrm{Fr}$ & Aug. ${ }^{\mathrm{D}}$ & - & - & - \\
\hline Hymenea courbaril & $\mathrm{Fr}$ & Sept. $^{D}$ & - & - & - \\
\hline unid. species & $\mathrm{Fl}$ & Apr. ${ }^{\mathrm{W}}$ & - & - & - \\
\hline \multicolumn{6}{|l|}{ MAGNOLIACEAE } \\
\hline Talauma ovata & $\mathrm{Se}$ & $\begin{array}{l}\text { July-Aug., Jan., } \\
\text { Mar.-Apr., June }\end{array}$ & 65.30 & 0.82 & 2.22 \\
\hline \multicolumn{6}{|l|}{ MALPIGHIACEAE } \\
\hline Byrsonima laxiflora & $\mathrm{Fr}$ & Sept.-Jan. ${ }^{\mathrm{B}}$ & - & 0.64 & - \\
\hline \multicolumn{6}{|l|}{ MELASTOMATACEAE } \\
\hline Miconia chartacea & $\mathrm{Fr}$ & Sept.-Oct. ${ }^{\text {B }}$ & - & 0.73 & - \\
\hline \multicolumn{6}{|l|}{ MELIACEAE } \\
\hline Guarea sp. & $\mathrm{Fr}$ & Aug. ${ }^{D}$ & - & - & - \\
\hline \multicolumn{6}{|l|}{ MIMOSACEAE } \\
\hline Inga cylindrica & $\mathrm{Fr}$ & Nov. ${ }^{\mathrm{W}}$ & 36.90 & - & - \\
\hline
\end{tabular}


Table 1. Continued...

\begin{tabular}{|c|c|c|c|c|c|}
\hline Species & $\begin{array}{c}\text { Part } \\
\text { eaten* }\end{array}$ & Month** & $\begin{array}{l}\text { Density }^{* * * *} \\
\left(\text { ind.ha }^{-1} \text { ) }\right.\end{array}$ & $\begin{array}{c}\text { Percentage of } \\
\text { feeding records }\end{array}$ & $\begin{array}{c}\text { Percentage } \\
\text { of foraging } \\
\text { records }\end{array}$ \\
\hline Inga heterophylla & $\mathrm{Fr}$ & Sept.-Nov. ${ }^{\text {B }}$ & - & 1.18 & 0.09 \\
\hline Inga ingoides & $\mathrm{Fl}, \mathrm{Fr}$ & $\begin{array}{l}\text { July-Sept., } \\
\text { Nov.-Dec. }\end{array}$ & - & 6.9 & 0.09 \\
\hline Inga sp. & $\mathrm{Fr}$ & Sept. ${ }^{D}$ & - & - & - \\
\hline \multicolumn{6}{|l|}{ MORACEAE } \\
\hline Ficus sp. 1 & Fr & Aug.-Sept. ${ }^{\mathrm{D}}$ & 32.60 & 2.45 & 0.09 \\
\hline Ficus sp. 2 & Fr & Apr. $^{W}$ & 32.60 & 0.45 & - \\
\hline \multicolumn{6}{|l|}{ MYRSIANCEAE } \\
\hline Rapanea guianensis & $\mathrm{Fr}$ & Nov. ${ }^{\mathrm{W}}$ & 65.30 & 1.36 & - \\
\hline \multicolumn{6}{|l|}{ MYRTACEAE } \\
\hline Myrcia rostrata & $\mathrm{Fl}$ & Dec. $^{\mathrm{w}}$ & 163.20 & 0.09 & - \\
\hline Myrcia tomentosa & $\mathrm{Fr}, \mathrm{Fl}$ & Sept., Nov.-Jan. ${ }^{\text {B }}$ & 456.90 & 0.09 & - \\
\hline Psidium guajava & Fr & Nov.-Mar. ${ }^{\mathrm{W}}$ & - & 5.63 & 1.30 \\
\hline Syzygium jambolana & $\mathrm{Fr}$ & Jan. $^{\mathrm{W}}$ & - & 0.27 & - \\
\hline \multicolumn{6}{|l|}{ PALMAE/ARECACEAE } \\
\hline Acrocomia aculeata & Fr & Aug.-Sept., Apr. ${ }^{\text {B }}$ & - & - & 0.09 \\
\hline Syagrus romanzoffiana & Fr & Aug. ${ }^{\mathrm{D}}$ & - & - & - \\
\hline \multicolumn{6}{|l|}{ PASSIFLORACEAE } \\
\hline Passiflora sp. 1 & - & Nov. ${ }^{\mathrm{w}}$ & - & 0.36 & 0.28 \\
\hline Passiflora sp. 2 & - & Feb. $^{\mathrm{W}}$ & - & - & 0.19 \\
\hline \multicolumn{6}{|l|}{ PIPERACEAE } \\
\hline Piper sp. 1 & Infl, Infr & Aug.-Apr. ${ }^{B}$ & 65.30 & 4.54 & 1.48 \\
\hline Piper sp. 2 & Infl, Infr & Aug.-Apr. ${ }^{B}$ & - & 1.82 & - \\
\hline \multicolumn{6}{|l|}{ POACEAE } \\
\hline Olyra latifolia & Le, $\mathrm{Pi}$ & $\begin{array}{l}\text { July-Sept., Dec.- } \\
\text { Jan., Mar.-Apr. }{ }^{B}\end{array}$ & - & 1.36 & 0.83 \\
\hline unid. species & $\mathrm{Le}$ & Mar. ${ }^{\mathrm{W}}$ & - & 0.18 & - \\
\hline \multicolumn{6}{|l|}{ RUTACEAE } \\
\hline $\begin{array}{l}\text { Zanthoxylum rhoifolium } \\
\text { SAPOTACEAE }\end{array}$ & $\mathrm{Fr}$ & Feb.-Mar. ${ }^{\mathrm{W}}$ & 32.60 & 5.54 & 1.85 \\
\hline $\begin{array}{l}\text { Chrysophyllum } \\
\text { marginatum }\end{array}$ & Fr & Aug.-Oct. ${ }^{B}$ & 163.20 & 0.73 & - \\
\hline \multicolumn{6}{|l|}{ SOPHOREAE } \\
\hline Ormosia paraensis & $\mathrm{Se}$ & July-Aug. ${ }^{\text {D }}$ & - & - & 0.19 \\
\hline \multicolumn{6}{|l|}{ TILIACEAE } \\
\hline Luehea divaricata & $\mathrm{Se}, \mathrm{Fl}$ & $\begin{array}{l}\text { Aug.-Sept., } \\
\text { Mar.-Apr. }\end{array}$ & - & 3.81 & 0.37 \\
\hline \multicolumn{6}{|l|}{ VOCHYSIACEAE } \\
\hline Vochysia tucanorum & $\mathrm{Fr}$ & Aug. ${ }^{\mathrm{D}}$ & - & - & - \\
\hline Invertebrates & - & Aug.-July ${ }^{B}$ & - & 5.00 & 52.27 \\
\hline Vertebrates & - & Oct., Jan.-Apr. ${ }^{\mathrm{W}}$ & - & 0.54 & 0.56 \\
\hline Unid. natural food & & & & 11.35 & 6.67 \\
\hline
\end{tabular}

*Fr = fruit, $\mathrm{Se}=$ seed, $\mathrm{Fl}=$ flower, $\mathrm{Infl}=$ inflorescence, $\mathrm{Infr}=$ infrutescence, $\mathrm{Le}=$ leaf, $\mathrm{Sp}=$ sprout, $\mathrm{Pi}=$ pith; **W $=$ wet season, $\mathrm{D}=$ dry season, $\mathrm{B}$ = both seasons; and ***Data from Ramos (1995). 
Table 2. Artificial foods eaten/foraged by the study group

\begin{tabular}{lcc}
\hline \multicolumn{1}{c}{ Food type } & Percentage of feeding records & Percentage of foraging records \\
\hline Fruit juice/soft drinks & 1.91 & 2.13 \\
Sweets (candy, cookies, cakes) & 3.91 & 1.67 \\
Fruit & 11.08 & 3.61 \\
Milk and by-products & 1.82 & 0.37 \\
Corn, sugar cane & 3.27 & 1.02 \\
Cooked foods, sauces, snacks & 8.63 & 2.41 \\
unid. human food & 4.45 & 10.29 \\
\hline
\end{tabular}

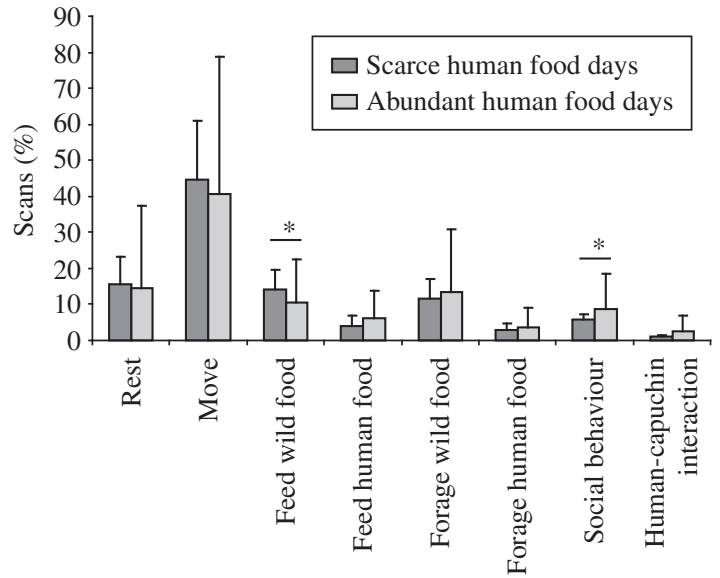

Figure 4. Capuchins' activity budgets during days in which visitors and their food were scarce (grey bars) and in which visitors and their food were abundant (black bars), expressed as mean percent of scans ( \pm standard error) in which each behavior was recorded. $* \mathrm{p}<0.05$.

into the diet is evidence of behavioral flexibility since it requires overcoming the initial avoidance response (Visalberghi et al., 2003).

Seasonality as well as human food affected the diet and activity budget of the group of bearded capuchin monkeys living in the Brasília National Park. During the dry season capuchins ate more human food, flowers and seeds than in the wet season, during which they ate more fruits and invertebrates. In fact, in semi-deciduous forests pulpy fruits are less abundant than in wet forests (Morellato and Leitão-Filho, 1992) and this lower food availability prompts capuchins to find alternative strategies to fulfill their energy requirements. Galetti and Pedroni (1994) also found seasonal differences in the diet of capuchins living in a semi-deciduous forest in South-Eastern Brazil. Recently, Moura (2004) argued that Cebus libidinosus living in the very dry caatinga overcame food shortage using tools to eat tubers and palm nuts; the alternative strategy developed by our capuchins was to exploit human food.

The use of the different forest strata is affected by the vegetation structure and by the availability of food at different heights. Capuchins are described as main- ly arboreal monkeys using the medium and low forest strata (Fleagle et al. 1981; Terborgh 1983), but they sometimes show a wide use of the forest floor (Siemers, 2000; Moura, 2004). In particular, Siemers (2000) reported that the main factor that favored the presence of capuchins in the forest floor during the dry season was the higher availability of food dropped by humans on the ground. During the dry season, our capuchins used the lowest height classes more than in the wet season also in the area of the swimming pools, since by staying at those heights, they enhanced the opportunities to obtain human food. Our results also showed that during the dry season they used the substrates comprised between 15 and $20 \mathrm{~m}$ significantly more. An explanation for this could be that during the dry season capuchins foraged at 15-20 m on trees of Cariniana estrellensis, a species whose very hard and thick pericarps are morphological adaptations to protect their fatty and protein-rich seeds from predators. Capuchins overcame the seed protection mechanism using very hard substrates to bang the fruits on. Capuchins not only banged the fruit against the tree as reported by Peres (1991), but frequently took the already fallen fruits, that they banged on artificial substrates, such as concrete sidewalks. The latter type of food processing increased the time that capuchins spent on the ground in the dry season.

Table 3 reports the activity budgets of capuchins of the National Park of Brasília and those of other wild Cebus libidinosus groups reported in the literature. The percentage of time devoted to the different activities are rather similar across study sites, with the exception of foraging: our capuchins foraged and fed on wild food to a lesser extent than other wild capuchins living in the other sites where human disturbance was lower, or nonexistent. In particular, the percentage dedicated to foraging by our group is smaller than reported for the group of similar dimension studied by Vilela (2003) in a protected semi-deciduous forest area near Brasília. Since the major ecological difference between these groups is the presence of visitors and visitors' food, this finding strongly supports the idea that human food affects capuchins' activity budget.

Our findings confirm those already reported for other monkey species relying on human food as a resource (Forthman Quick, 1986; Lee et al., 1986; O'Leary and 
Table 3. Activity budgets of wild groups of Cebus libidinosus.

\begin{tabular}{clccccccc}
\hline \multicolumn{1}{c}{ Species } & \multicolumn{1}{c}{ Habitat } & $\begin{array}{c}\text { Group } \\
\text { size }\end{array}$ & $\begin{array}{c}\text { Move } \\
(\boldsymbol{\%})\end{array}$ & $\begin{array}{c}\text { Rest } \\
(\boldsymbol{\%})\end{array}$ & $\begin{array}{c}\text { Feeding } \\
(\boldsymbol{\%})\end{array}$ & $\begin{array}{c}\text { Foraging } \\
(\boldsymbol{\%})\end{array}$ & $\begin{array}{c}\text { Social } \\
\text { behavior } \\
(\boldsymbol{\%})\end{array}$ & Source \\
\hline Cebus libidinosus & $\begin{array}{l}\text { Semi-deciduous } \\
\text { tropical forest }\end{array}$ & 8 & 41 & 15 & $17 *$ & $17 *$ & 8 & Present study \\
Cebus libidinosus & $\begin{array}{l}\text { Semi-deciduous } \\
\text { tropical forest }\end{array}$ & 7 & 38 & 14.5 & 18 & 29.5 & - & Vilela (2003) \\
Cebus libidinosus & $\begin{array}{l}\text { Dry tropical } \\
\text { forest }\end{array}$ & 10 & 37.1 & $\sim 5.5$ & 19.6 & 22.3 & $\sim 6.5$ & Moura (2004) \\
\hline
\end{tabular}

*Data on feeding and foraging behaviors refers to human and wild food pooled.

Although Vilela (2003) and Moura (2004) labelled the species studied Cebus apella libidinosus, according to a new taxonomy, capuchins living in those areas are considered Cebus libidinosus.

Fa, 1993; Saj et al., 1999). In fact, our results showed that capuchins decreased the time spent foraging and modified the target of their food searches mostly when the visitors were present and the possibility of eating their food arose. Since the majority of the interactions involved the presence of food (Sabbatini et al., 2006), we argue that the time spent interacting with visitors by the capuchins (2\%) can be considered a sort of foraging.

Another factor affecting capuchins' behavior is the number of visitors: capuchins spent more time in the forest and ate more natural foods when human food was scarce than when it was abundant. In fact, when there were less visitors and less human food available, our group of capuchins fed more on natural food sources and interacted less with humans.

In conclusion, the consumption of human food we documented reflects the adaptability of capuchins to exploit alternative concentrated and abundant food sources (Terborgh, 1983) and their ability to modify their diet and behavioral patterns in response to changing environmental conditions. As Forthman Quick (1986) suggested, the nature of costs and benefits, spatial and temporal distribution, seasonality, age composition are all factors contributing to alterations in activity patterns. In our case, the food provided more or less directly by visitors was preferred because of being easy to obtain and digest, and was very likely with a higher caloric content than most natural food. Although chemical analyses of wild and artificial food eaten by our capuchins were not carried out, human food has been reported to be more energetic than wild food eaten by monkeys (e.g., Lee et al., 1986; Fa, 1986; Saj et al., 1999; Muruthi et al, 1991). Moreover, human food represents a staple food source during periods of natural food shortage, its spatial concentration and the abundance in the swimming pool area modified activity budgets and possibly restricted the ranging pattern. Research contributing to knowledge of the impact of humans' presence on animal behavior should be taken into account by Park administration when allowing people to visit and enjoy natural environments.

Acknowledgements - We thank the National Park of Brasília and, in particular, the director Dr E. M. da Silva Jr for permission to conduct fieldwork and to use the Park's accommodation. We thank the Universidade de Brasília and all the people at the Laboratorio de Neurociências e Comportamento for their collaboration. We are grateful and indebted to P. Pinha, I. Waga and R. T. Souza for their help in the field observations and data collection, and to Prof. L. M. Breyer (Depto de Botânica, Instituto de Biologia, UnB) and Dr E. S. G. Guarino (Depto de Zoologia, Instituto de Biologia, UnB) for the help with botanical species identification. A special thanks to Prof. P. Izar and an anonymous reviewer for their useful comments on early versions of the manuscript. G. Sabbatini received financial support form the Università "La Sapienza" di Roma and from the Centro Studi Etologici-Ethoikos (LIBCSE 01/2004), M. Stammati received financial support from the Università "La Sapienza" di Roma. Research Fund was granted by UnB/IB Edital Royalties 2003 and FINATEC.

\section{References}

ALTMANN, J., 1974. Observational study of behaviour: sampling methods. Behaviour, vol. 49, no. 3, p. 227-267.

BROWN, AD. and ZUNINO, GE., 1990. Dietary variability in Cebus apella in extreme habitats: evidence for adaptability. Folia Primatol., vol. 54, no. 3-4, p. 187-195.

CHAPMAN, CA. and FEDIGAN, LM., 1990. Dietary differences between neighboring Cebus capucinus groups: local traditions, food availability or responses to food profitability? Folia Primatol., vol. 54, no. 3-4, p. 177-186.

CHIVERS, DJ., 1991. Species differences in tolerance to environmental change. In Box, HO. (Ed.). Primate Responses to Environmental Change. London: Chapman and Hall.

FA, JE., 1986. Use of time and resources by provisioned troops of monkeys: social behaviour, time and energy in the barbary macaque (Macaca sylvanus) at Gibraltar. New York: Karger.

FLEAGLE, JG., MITTERMEIER, RA. and SKOPEC,AL., 1981. Differential habitat use by Cebus apella and Saimiri sciureus in Central Surinam. Primates, vol. 22, no. 3, p. 361-367.

FORTHMAN-QUICK, DL., 1986. Activity budgets and the consumption of human food in two troops of baboons, Papio anubis, at Gilgil, Kenya. In Else, JG. and Lee, P.C. (Eds.). Primate ecology and conservation. Cambridge: Cambridge University Press. 
FRAGASZY, DM., FEDIGAN, L., VISALBERGHI, E., 2004. The Complete Capuchin. The Biology of the Genus Cebus. Cambridge: Cambridge University Press.

GALETTI, M. and PEDRONI, F., 1994. Seasonal diet of capuchin monkeys (Cebus apella) in a semidecidous forest in south-east Brazil. J. Trop. Ecol., vol. 10, no. 1, p. 27-39.

GROVES, C.P., 2001, Primate Taxonomy. Washington, D.C.: Smithsonian Institution Press.

HAWKES, K., HILL, K. and O'CONNELL, JF., 1982. Why hunters gather: optimal foraging and the Achè of eastern Paraguay. Am. Ethnol., vol. 9, no. 2, p. 379-398.

IZAR, P., 2004. Female social relationships of Cebus apella nigritus in a southeastern Atlantic Forest: an analysis through ecological models of primate social evolution. Behaviour, vol. 141, no. 1, p. 71-99.

JANSON, CH., 1985. Aggressive competition and individual food consumption in wild brown capuchin monkeys (Cebus apella). Behav. Ecol. Sociobiol., vol. 18, no. 2, p. 125-138.

LEE, PC., BRENNAN, EJ., ELSE, JG. and ALTMANN, J., 1986. Ecology and behaviour of vervet monkeys in a tourist lodge habitat. In Else, JG. and Lee, PC. (Eds.). Primate ecology and conservation. Cambridge: Cambridge University Press.

LEE, PL. 1991. Adaptations to environmental change: an evolutionary perspective. In Box, HO. (Ed.). Primate Responses to Environmental Change. London: Chapman and Hall.

MENDES, FDC., ROCHA, SAA., BALESTRA, R., GUIMARÃES, ZFS. and PORTELA, RC., 2005. Padrões comportamentais de Cebus apella libidinosus em fragmentos de matas urbanas: adaptabilidade, problemas de convivência e manejo. In Abstracts del XI Congreso Brasileiro de Primatologia. Porto Alegre, Brasil: FaBio/PUCRS: Soc. Brasileira de Primatologia. p. 39.

MIKICH, SB., 2005. O macaco-prego, Cebus apella nigritus, em fragmentos da Floresta Estacional Semidecidual do Estado do Paraná, Brasil: Super-população e implicações para a conservação dos remanescentes florestais. In Abstracts del XI Congreso Brasileiro de Primatologia. Porto Alegre, Brasile: FaBio/PUCRS: Soc. Brasileira de Primatologia. p. 51.

MORELLATO, LPC. and LEITÃO-FILHO, HF., 1992. Padrões de frutificação e dispersão na Serra do Japi. In Morellato, LPC. (Ed.). História natural da Serra do Japi. Campinas: Editora da Unicamp-Fapesp, Brasil.

MOURA, ACA., 2004. The capuchin monkey and the Caatinga dry forest: a hard life in a harsh habitat. Cambridge: University of Cambridge. [PhD Dissertation].

MURUTHI, P., ALTMANN, J. and ALTMANN, S., 1991. Resource base, parity, and reproductive condition affect females' feeding time and nutrient intake within and between groups of a baboon population. Oecologia, vol. 87, no. 4, p. 467-472.

IBAMA. Database, 2003. Disponível em: http://www.ibama. gov.br/revista/brasilia/texto_brasilia.htm (10/1/2003)

O'LEARY, H. and FA, J.E., 1993. Effects of tourists on barbary macaques at Gibraltar. Folia Primatol., vol. 61, no. 2, p. 77-91.

PERES, CA., 1991. Seed predation of Cariniana micrantha (Lecythidaceae) by brown capuchin monkeys in Central Amazonia. Biotropica, vol. 23, no. 3, p. 262-270.

-, 1994. Primate response to phenological changes in an amazonian terra firme forest. Biotropica, vol. 26, no. 1, p. $98-112$.

PHILLIPS, K., 1995. Resource patch size and flexible foraging in white-faced capuchins (Cebus capucinus). Int. J. Primatol., vol. 16 , no. 3 , p. 509-519.

RAMOS, PCM., 1995. Vegetation communities and soils in the National Park of Brasilia. Edinburgh: University of Edinburgh. [PhD thesis].

RICHARD, AF., GOLDSTEIN, SJ., DEWAR, RE., 1989. Weed macaques: The evolutionary implications of macaque feeding ecology. Int. J. Primatol., vol. 10, no. 6, p. 569-594.

ROBINSON, JG., 1986. Seasonal variation in the use of time and space by the wedge-capped capuchin monkey, Cebus olivaceus: implication for foraging theory. Smithsonian Contrib. Zool., vol. 431, no. 1, p. 1-60.

SABBATINI, G., STAMMATI, M., TAVARES, MCH., GIULIANI, MV., and VISALBERGHI, E., 2006. Interactions between humans and capuchin monkeys (Cebus libidinosus) in the Parque Nacional de Brasília, Brazil. Appl. Anim. Behav. Sci., vol. 97 , no. 2 , p. $272-283$.

SAJ, T., SICOTTE, P., and PATERSON, JD., 1999. Influence of human food consumption on the time budget of vervets. Int. J. Primatol., vol. 20, no. 6, p. 977-994.

SCHOENER, TW., 1970. Non-synchronous spatial overlap of lizards in patchy habitats. Ecology, vol. 51, no. 33, p. 408-418.

SIEMERS, BM., 2000. Seasonal variation in food resource and forest strata use by brown capuchin monkeys (Cebus apella) in a disturbed forest fragment. Folia Primatol., vol. 71, no. 3, p. $181-184$.

TERBORGH, J., 1983. Five New World Primates: a Study in Comparative Ecology. New Jersey: Princeton University Press.

VILELA, SL., 2003. Simpatria de Alouatta caraya, Cebus apella e Callithrix penicillata em matas de galeria do Distrito Federal. Brasília: Universidade de Brasília. [PhD thesis].

VISALBERGHI, E., JANSON, CH., and AGOSTINI, I., 2003. Response toward novel foods and novel objects in wild Cebus apella. Int. J. Primatol., vol. 24, no. 3, p. 653-675. 